\title{
Transfer and accumulation of cadmium in soil, forages and animals: Risk assessment
}

\author{
Razia Sultana ( $\square$ sidra4498@gmail.com ) \\ University of Sargodha Faculty of Sciences \\ Xiaoping Ge \\ Hohai university
}

\section{Fu Chen}

China University of Mining Technology: China University of Mining and Technology

\section{Sidra Anwar}

University of Sargodha

Jing Ma

China University Mining and Technology

\section{Kafeel Ahmad}

University of Sargodha Faculty of Sciences

\section{Zafar lqbal Khan}

University of Sargodha Faculty of Sciences

\section{Asma Ashfaq}

University of Sargodha

\section{Muhammad Nadeem}

University of Sargodha Pakistan

\section{Tasneem Ahmed}

Pakki Thatti Research and Development Farm

\section{Ilker Ugulu}

China University Mining and Technology

\section{Research Article}

Keywords: Sources, automobiles, accumulation, Daily intake of metals

Posted Date: May 4th, 2021

DOI: https://doi.org/10.21203/rs.3.rs-363509/v1

License: (c) (i) This work is licensed under a Creative Commons Attribution 4.0 International License. Read Full License 


\section{Abstract}

Over past several years pollution in industrialized areas is the most attention seeking issue. Higher level of heavy metals especially cadmium is accumulated in atmosphere evolved from smoke of automobiles. Living system present around the contaminated areas accumulate heavy metals in their bodies. Heavy metals have been accumulated in soil, water, forages and animals so study was conducted in industrialized area Faisalabad to evaluate the possible risk. Three sites was selected to check the accumulation of cadmium in soil, water, forages and animals. These sampling sites was areas along the roadsides of Chak Jhumra, Jaranwala and Samundri. Sample of soil, forages,water and blood,hair feces of animals was collected from these sites. The digestion of samples was carried out with the help of nitric acid and hydrogen peroxide. Atomic absorption spectrophotometer was used to evaluate heavy metal analysis. Analysis of variance was done by using SPSS Software (version no. 20) and two ways ANOVA. Result indicated that concentration of $\mathrm{Cd}$ was higher in soil irrigated with municipal wastewater and concentration of $\mathrm{Cd}$ was highest in forages $\mathrm{C}$. album present at site III. Higher concentration of Cd was observed in blood of sheep higher than critical value. Concentration of cadmium was higher than critical in blood of animals indicating transfer of metal via intake of contaminated forages. The sample collected from site III showed high daily intake of metals (DIM), health risk index (HRI), pollution load index (PLI), enrichment factor (EF) and Bioconcentration factor (BCF). This study will bring consideration concerning the development of approaches in order to overcome the toxic effects of cadmium.

\section{Introduction}

Any metallic element that have higher density than water are termed as heavy metal(1a) many natural as well as anthropogenic activities (scorching of fossil fuel, mining operations, metallurgy industry, means of traveling) have distributed toxic metals in environment. these metals linger for extended duration ultimately effecting all the components of environment (Kaplan et al.2010). Over the past several years these toxic metals contamination associated with the ecologic as well as public health issues. Use of toxic metals in various daily based activities including (technical, manufacturing activities, household, farming) have increased human exposure to toxic metals (Bradl, H.,2005). separate researches have been conducted to investigate the effect of various metals in soil, water air and plants (Kabata Pendias.,2001; Kabata Pendias.,2007). plant considered as good bio-indicators for presence of metal at particular soil as plant could absorb metals naturally. They are intermediate medium by which metals move from soil, forages to animals and humans (Kabata Pendias.,2007) in case of lead small quantity of Pb absorbed by the roots of plants and its subsequent transfer to aerial parts limited (Kabata Pendias.,2001). Toxic metals are gathered in vegetation, and faunas nourished on these vegetation resulting in accumulation of lethal metals. Wastewater contain most persistent contaminants known as heavy metals and trace metals. Many environmental danger are produced by the liberation of toxic metals into water especially in enormous amount. Heavy metals are exposed to humans by different ways some of these are by eating and drinking contaminated food and water, evaporation, breathing in air full of dust and smoke. Toxicity due to pollutants may be long or short term basis and water ecological unit is also effected by the heavy metals by expiring biota, eutrophication, reduction of locale as a result of sediment formation and waterlogging. Metabolism and functional processes that result in nutrient uptake and growth of fodder crops can be prevented by the heavy metals in soils present in large number and lessen the superiority and magnitude of food obtain. Animals are also threatened by the heavy metals as some effects caused by metals can lead to death these effects includes ,tumor formation, malfunctioning of nerves and different body parts. Numerous chemical or natural strategies are suggested by the researchers in order to overcome the destructive effects of toxic material on all the organisms living or non-living. For the avoidance of availability of heavy metals in soil and water treatment method of wastewater supplied to the irrigated fodder crops are vital by using natural avoidance method by the plants or different microbiota (bacteria, fungi, algae, protozoa) living in soil near the crops grown these help to restore the surrounding (Akpor et al.2014). Various districts of Punjab was studied to examine heavyweight elements metals pollution and their 
occurrence in soil, water, forages, animals and humans and appraisal of health problems due to different activities which may be related to industries, farming, extraction of minerals and other ordinary procedure. Cadmium concentration in Sargodha, Mianwali and Bhakkar higher concentration found in Sargodha 4.57 to 4.94, 2.98 to 3.95 in mianwali, and least concentration found in bhakar which is from 1.65 to $2.98 \mathrm{mg} / \mathrm{kg}$. forages of Sargodha contain cadmium level from 2.745-3.432 in Mianwali forages have 2.245-3.196 cadmium values and forages of bhakkar contain cadmium $1.9-2.036 \mathrm{mg} / \mathrm{kg}$. blood of goat and sheep grazing on a contaminated forages which is grown in contaminated soil is examined and it shows that the values of cadmium in goat and sheep of Sargodha is between 2.152-2.436, 2.152 to $2.436 \mathrm{mg} / \mathrm{L}$ correspondingly. Goat and sheep of Mianwali contain cadmium level 1.727-2.39, 1.794 to $2.286 \mathrm{mg} / \mathrm{L}$ respectively and in district bhakkar cadmium level in blood of goat and sheep is 2.3-2.62, 1.97 to $2.066 \mathrm{mg} / \mathrm{L}$ correspondingly. These values are within the acceptable values as set by the WHO (Khan et al.2019). Aim of present study was to investigate the concentration of cadmium in soil and transfer of cadmium in soil-plant-animal systems

\section{Materials And Methods}

\section{Location}

The study area Faisalabad district is an area of Punjab, Pakistan. This is a industrial area where most of the crops are grown in wastewater. Different fodder crops and forages are being cultivated in a wastewater directly or indirectly. This city of Pakistan is well-known for its industrial activities are contributing to the economy of country as well as to the growing pollution in the region. High traffic are being observed in this city which is largely due to the population explosion which is ultimately increasing demand for food. Conferring to the 1998 survey of Pakistan. Faisalabad is the $3^{\text {rd }}$ biggest city of Pakistan after Karachi and Lahore. Faisalabad ranges above an area of 5856 Square kilometers comprehending of subsequent eight tehsils. The specimens of available soil, forages, fodder crops and blood of animals are collected from three different sites of GW I Chak Jhumra, CW II Jaranwala, MWW III Jaranwala of District Faisalabad. Three replicates of sample are collected from each site. Sampling was done in Aug-2019 to May 2020.

\section{Climate}

Regular yearly precipitation is around 615 millimeters (24.2 in).Summer season is hot and dry but during the month of July and August monsoon season brings rainfall. Monsoon season ends in September passes precipitation beginning loud overflowing. July is the rainiest duration yearly result in flood. winter season brings considerable rainfall accompanying with hail.

\section{Vegetation}

District Faisalabad is primarily urban area with industrial and agricultural activities. Along with the large production of vegetables food crops are also cultivated to fulfill the feeding requirements of livestock as well as human beings. These crops includes kharif crops and Rabi crops Kharif Fodder Crops Guar maize, sorghum S.S. Hybrid, millet etc Rabi Fodder Crops berseem Lucerne mustard Rape \& Mustard. Major fruit production includes citrus, guava and mangoes

\section{Collection of sample}

\section{Forage samples}

samples of four forages have been collected. This specimens selection ware executed in five duplicates of every specimen for each place. Samples of Berseem, Brassica, sugar beet, sugar cane have been collected from the roadsides of each site. Samples of forages have been exposed to dry in the air and in oven at $75^{\circ} \mathrm{C}$ for week. When sample was completely dried this was subjected to grind into powder form and $2 \mathrm{~g}$ sample was taken for further digestion process. 


\begin{tabular}{|c|c|c|}
\hline Sr. No & Botanical name & Common name \\
\hline $\mathbf{1}$ & Beta vulgaris & Chokandar \\
\hline 2 & Brassica campestris & Mustard or SAAG \\
\hline 3 & Trifolium alexandrinum & Barseem \\
\hline 4 & Saccharin officinarum & Sugarcane \\
\hline
\end{tabular}

\section{Soil Samples}

$1 \mathrm{~kg}$ soil sample were collected along with forages about 30 soil sample were collected. Soil sample were weighed in order to check the moisture content then soil sample were air dried for 24 hours then these sample were further dehydrated in microwave to remove moisture content was removed from the soil. Then these samples have been beaten using pestle mortar and about $2 \mathrm{~g}$ of every sample used to be saved for the in addition technique after sieving of all samples.

\section{Water samples}

Water which is supplied to the relevant fodder collected were also taken in 1 Litre bottles from each site. $5 \mathrm{ml}$ were stored for additional digestion

\section{Apparatus and chemical}

Gloves, hotplate, four beakers $100 \mathrm{ml}$ and $250 \mathrm{ml}$, two hydrogen peroxide $\left(\mathrm{H}_{2} \mathrm{O}_{2}\right) 50 \%$, filter paper, two digestion flasks of $100 \mathrm{ml}$, Sulphuric acid $2 \mathrm{ml}$, Tripod stands, stirrer, freshly prepared distilled water, $50 \mathrm{ml}$ measuring cylinder and small plastic bottles.

\section{Dry digestion}

Dry digestion was carried out in order to decompose all the natural rely in the samples of forage and soil. Principally made to obtain:

- Thorough disintegration of biological environment

- Avoiding impurity

- A whole solution of matrix (Jones, 1984)

\section{Weighing each crucible}

Before performing dry digestion each crucible were weighted and noted by using weigh balance.

\section{Forage}

Forage $(5 \mathrm{~g})$ were added in each crucible and again weight of crucible+ forage noted. It was heated until the formation of ash and then after drying this ash is kept for 24 hours. Ash weighted again and dissolve in 50ml water and kept it for metal analysis.

\section{Soil}

Soil $(5 \mathrm{~g})$ added in digestion chamber along with $2 \mathrm{ml}$ sulfuric acid.Entire concentration of toxic minerals in soil has been investigated afterward the digestion. About $2.5 \mathrm{ml}$ of nitric acid, $0.5 \mathrm{ml} 30 \%$ hydrogen peroxide and $7.5 \mathrm{ml}$ of hydrochloric 
acid have been used (Kilburn, 2000).

Water

Few drops of sulfuric acid were added in beaker containing $5 \mathrm{ml}$ of water and boil it until the appearance of smoke then $2 \mathrm{ml}$ of hydrogen peroxide was added process was repeated until and unless water becomes clear by using filter paper water was filtered and filled in a bottle.

\section{Dilution and filtration}

All the digested samples have been diluted via freshly prepared distilled water making their extent up to 50ml. The dilution of the samples used to be followed through their filtration and labeling. All the samples have been then saved in plastic bottles

\section{Metal analysis}

All the processed samples are then analyzed through Atomic Absorption Spectrophotometer to find heavy metal concentration in samples.

\section{Statistical analysis}

Data obtained from soil, forage, and blood samples were investigated and mean contents of heavy metals were present in each replicate. Variance and correlation were determined using SPSS Software and two way ANOVA.

\section{Indices for pollution exposure assessment}

\section{Pollution load index}

Pollution load index was calculated (Liu et al. 2005).

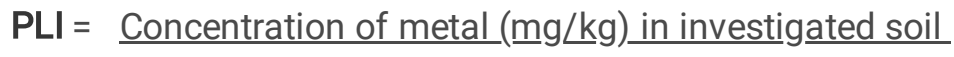

Reference value of metal in soil

\section{Bioconcentration factor}

Bioconcentration factor (BCF) was used by Cui et al. 2004

BCF soil-f orage $=$ Concentrations of metals in forage

Concentrations of metals in soil

BCF forage-plasma $=\underline{\text { Concentrations of metals in plasma }}$

Concentrations of metals in forage

\section{Enrichment factor (EF)}

Enrichment factor is calculated by formula

Enrichment factor $(E F)=($ Conc. of metal in plant/Conc. of metal in soil $)$ sample

(Conc. of metal in plant/Conc. of metal in soil) standard 


\section{Daily intake of metals}

The formula to find the daily intake of metals (DIM) is:

DIM $=C_{\text {metal }}$ * $D_{\text {food intake }} / B_{\text {average weight }}$

\section{Health risk index.}

Health risk index abbreviated as HRI and used to find out health risk associated with intake of contaminated forage.

(Cui et al. 2004; USEPA 2002).

$H R I=D I M / R_{f} D$

DIM = Daily intake of heavy metal

$R_{f} D=$ Oral reference dose

\section{Cadmium}

Result of variance analysis indicated that there was significant effect on Cd concentration by site and non-significant effect at soil and site*soil. Analysis of variance for data of forages indicated that significant effect was showed on concentration of $\mathrm{Cd}$ at site, forages and site* forages. Analysis of variance of data Indicated Significant Effect on Cd concentration at site and animal*source while non-significant effect of metal in animal, source, site*animal, site*source, site*animal*source. Analysis of variance for data showed significant effect on cd concentration in water as presented in (Table 2).

\section{Soil}

Amount of cadmium diversified from to 0.80 to $1.93 \mathrm{mg} / \mathrm{kg}$ in soil samples collected from different sites. Greatest concentration was present in soil of Trifolium alexandrinum at site provided with municipal wastewater and lowest concentration was present in soil of Saccharin officinarum at site watered with ground water. (Table 3) (figure 2). Present value lower than the reference values given by EU, $2002 \mathrm{FAO} / \mathrm{WHO}, 2001$ which is 3mg/kg.

\section{Forages}

The mean concentration of cadmium varied from 0.35 to $1.76 \mathrm{mg} / \mathrm{kg}$ in forages. Study indicates maximum level of metals was present in C. album which was initially provided with municipal wastewater. Minimum concentration was observed in S. officinarum (Table 3) (figure 3). Observed concentration of $\mathrm{Cd}$ is higher than Concentration given by FAO/WHO (2001) which is $0.2 \mathrm{mg} / \mathrm{kg}$.

\section{Animals}

Result of Cd analysis in blood of animals showed values ranging from 0.864 to $1.98 \mathrm{mg} / \mathrm{L}$. Concentration of Cu was highest in blood of cow at CW II while blood of sheep at GW I Showed lowest Cd concentration. Result of hair analysis showed variation from 0.91 to $2.03 \mathrm{mg} / \mathrm{kg}$. Maximum values present in hair of Buffalo at canal watering site and minimum concentration observed in hair of Buffalo at Municipal wastewater irrigated site. Feces of animals had shown Cd values varying from 0.961 to $2.32 \mathrm{mg} / \mathrm{kg}$.Largest amount was observed in feces of sheep at canal water irrigated site and smallest values was found in feces cow at municipal wastewater irrigated site (Table 4)

\section{Water}


Heavy metal analysis showed result of concentration of $\mathrm{Cd}$ in ground water varied from $0.42-0.71 \mathrm{mg} / \mathrm{L}$, while in canal water values varied from 1.06 to $1.29 \mathrm{mg} / \mathrm{L}$. Municipal waste water showed values from 0.94 to $1.12 \mathrm{mg} / \mathrm{L}$ (Table 5) (fig 4)

\section{Pollution load index (PLI), Bio-concentration factor (BCF), Enrichment factor (EF) of cadmium}

Higher BCF value was found in C .album at municipal waste water irrigated site while lower BCF value was observed in S. officinarum. Pollution Load index varied from 0.286 to $0.689 \mathrm{mg} / \mathrm{kg}$. Highest concentration was present in $T$ .alexandrinum and lowest concentration was observed in S. officinarum. EF values ranged from 1.77 to $10.32 \mathrm{mg} / \mathrm{kg}$. Maximum concentration was found in $C$.album at municipal wastewater irrigated site while minimum concentration was found in S. officinarum at municipal wastewater irrigated site (Table 6)

\section{Daily intake of metal (DIM) and Health risk index (HRI)}

Highest DIM of Cd was observed in sheep grazing at $C$. album while lowest DIM of metal was present in cow feeding on T.alexandrinum. Maximum HRI was observed in sheep eating $C$. album while minimum value was present in cow feeding S. officinarum. (Table 7)

\section{Discussion}

Nawab et al. (2015) noted that Cd concentration ranged from 0.5 to $8 \mathrm{mg} \mathrm{kg}^{-1}$ which is higher than our present concentration. Khan et al. (2013) studied the effect of wastewater irrigation in soil and reported Cd concentration 0.098$0.52 \mathrm{mg} / \mathrm{kg}$ lower than those observed by present study. Faiz et al. (2009) observed Cd concentration in the soil ranged between 5.8-6.1 mg kg collected from Islamabad city higher than present study. Cd can be toxic for human if exposed for a longtime it can damage kidney. Similar result was found by Liang et al. (2012) that Cd concentrations surveyed in five sites was ranging from 0.90 to $1.76 \mathrm{mg} / \mathrm{kg}$. Concentration of Cd revealed by current observation found higher than Iqbal et al. (2016). Karimi et al. (2020) reported higher concentration than current concentration. Similar result has been found by Yu et al. (2016) studied metal concentration in soil with sewage irrigation Different factor are responsible in transferring metal from soil to growing plants. Various researcher reported that availability of metal in soil effected by different factors for example $\mathrm{PH}$, carbon content age of growing fodder crops etc. it is obvious that availability depends upon metal content in soil its PH and type of soil. (Yu et al., 2016 : Mapanda et al., 2005). Current values lower than values observed by Khan et al., (2015). Similar finding was observed by Ruchuwararak et al.(2019). Our value was greater than critical limit $(1.1 \mathrm{mg} / \mathrm{L})$ noted by FAO/WHO (1996). Current result of Cd illustrated higher than reported by Yu et al. (2016)Absorption of cd by forages is largely greater as compared to other metals higher concentration of Cd surpasses the permissible limit and considered harmful for humans (Li et al., 1994).Cd is easily absorbed by forages and its buildup in human beings results in damage to vital organs including liver, brain and heart.(Tataruch and Kierdorf 2003).Khan et al. (2015) observed 2.15 to $9.50 \mathrm{mg} / \mathrm{kg}$ in different forages irrigated with wastewater these values are higher than our values. Okareh and Oladipo (2015) reported concentration of $\mathrm{Cd}$ in blood ranged from0.01 6.11 mg/L which was higher than current concentration. Present concentration were found above the critical limit which is $0.1 \mathrm{mg}$ /L (WHO 1983) Present study reported larger content than those informed by Gowda et al.(2003).Ubwa et al. (2017) reported lower concentration of cd in blood than present observed concentration. Reason of different concentration of $\mathrm{Cd}$ in blood of animals was due to Grazing of animals on contaminated area and drink contaminated water originated from different sources for example river, streams and ponds similar result was reported by Nwude et al.(2010). Present content of Cd was higher than critical limit of Cd in blood of animals $0.5 \mathrm{mg} / \mathrm{L}$ as observed by WHO (2000). (Krupa et al., 2006: Cygan-Szczegielniak et al., 2014 : Gabryszuk et al.,2008:Su et al., 2017) reported lower concentration of Cd in hair of animals than current observed concentration. Yang et al.(2017) studied cd content in feces of animals ranged from $0.01-8.7 \mathrm{mg} / \mathrm{kg}$. Sharma et al. (2006) suggested values of Cd in water varied from 0.02-0.04mg/L while Ahmed et al. 
(2010) noted values ranged from 0.02 to $0.08 \mathrm{mg} / \mathrm{L}$ both of the findings were Found lower than current observed concentration of $\mathrm{Cd}$ in irrigation water while safe limit of $\mathrm{Cd}$ in water was reported $0.01 \mathrm{mg} / \mathrm{L}(\mathrm{Pescod}, 1992)$ our concentration of Cd surpass this concentration. Alrawiq et al.(2014) reported BCF values varied from 0.221-0.490 $\mathrm{mg} / \mathrm{kg}$ lower than present study. Liu et al.(2005) reported that BCF > 1 indicates that metal is present. Rabee et al.(2011) studied greater PLI concentration than present observed concentration. Pollution load index is measurement tool to assess the heavy metal pollution. PLI greater than 1 indicate contamination by metal but PLI less than 1 showed metal is not causing pollution. ( Chakravarty and Patgiri 2009). Enrichment Factor varied from 44.3-102mg/kg showed very high enrichment of metal reported by suzuk et al.(2009) Which is higher than our value.

\section{Conclusion}

Heavy metal pollution becomes serious concern now a days.in this research heavy metals analysis of soil, forages and animals indicated higher concentration of cadmium in forages than allowable limit. Cadmium concentration in blood of animals was higher than critical limit.so consumption of such forages may not safe for animals grazing on it however further investigation on contamination of other forages is necessary.

\section{Declarations}

\section{Ethics declarations}

Conflict of interest: The authors declare that they have no conflict of interest.

Ethical approval: The authors declare that the manuscript has not been published previously.

Consent to participate: All authors voluntarily to participate in this research study.

Consent to publish: All authors consent to the publication of the manuscript.

Availability of data and materials: All data generated or ana-lyzed during this study are included in this published article.

Contributions: RS and AA were responsible for writing the manuscript. KA and ZIK supervised the study. Ayesha maqsood, Mudasra Munir, Ifra Malik,Sonaina Nazar, Mehwish amjad,Shahzad Akhtar and Muhammad Nadeem was responsible for conducting the experiments and the data analysis. Tasneem Ahmed, Fu chen, jing Ma and ilker ugulu helped in proof reading of Manuscript.

\section{Funding and Acknowledgement}

This work was supported by the National Natural Science Foundation of china (no 51974313,41907405 ) and the natural Science foundation of Jiangsu Province (no .BK20180641).

\section{Literature Cited}

Ahmed,J.U. and M.D. Abdulgoni .2010. Heavy metal contamination water, soil, and vegetables of the industrial areas in Dhaka, Bangladesh. Environ Monit Assess. 166:347-357.

Alrawiq, N., J.Khairiah, J.Talib, M.L.Ismail and B.S.Anizan .2014. Accumulation and translocation of heavy metals in soil and paddy plant samples collected from rice fields irrigated with recycled and non-recycled water in MADA Kedah, Malaysia. Int J ChemTech Res, 6(4): 2347-2356.

Bradl, H. (Ed.). 2005. Heavy metals in the environment: origin, interaction and remediation. Elsevier. 
Chakravarty, I. M and A.D. Patgiri. 2009. Metal Pollution Assessment in Sediments of the Dikrong River, N.E. India. J Hum Ecol, 27(1), 63-67

Cygan-Szczegielniak, D., M.Stanek and E.Giernatowska .2014. Impact of breeding region and season on the content of some traceelements and heavy metals in the hair of cows. Folia Biol 62:164-170

Dotaniya, M. L., C.K.Dotaniya, P.Solanki, V.D. Meena, R.K. Doutaniya .2020. Lead contamination and its dynamics in soil-plant system. In Lead in Plants and the Environment (pp. 83-98). Springer, Cham.

Faiz,Y., M.M. Tufail and C. Naila-Siddique .2009. Road dust pollution of Cd, Cu, Ni, Pb and Zn along Islamabad Expressway, Pakistan. Microchemical Journal 92:186-192

Gabryszuk, M., K.Słoniewski and T.Sakowski .2008 Macro- and mi-croelements in milk and hair of cows from conventional vs. organicfarms. Anim Sci Paper Rep 26:199-209.

Gowda, N.K.S, V.S.Malathi , S.Jash , K.S.Roy .2003. Status of pollutants and trace elements in water, soil, vegetation and dairy animals in industrial area of Bangalore. Ind J Dairy Sci 56:86-90.

Iqbal,H.H., R.Taseer , S.Anwar ,M. Mumtaz, A.Qadir, N.Shahid .2016. Human health risk assessment: heavy metal contamination of vegetables in Bahawalpur, Pakistan. Bull Environ Stud 1:10-17

Kabata Pendias, A. 2001. Trace Elements in Soils and Plants. 3rd ed. CRC Press, Boca Raton, FL. 2.

Kabata Pendias, A. and Mukherjee, A. 2007. Trace Elements from Soil to Human. Springer- $\quad$ Verlag, Berlin Karimi, A., A.Naghizadeh, H. Biglari, R. Peirovi, A. Ghasemi, A.Zarei. 2020. Assessment of human health risks and pollution index for heavy metals in farmlands irrigated by effluents of stabilization ponds. Environmental Science and Pollution Research, 1-11.

Khan, K., Y.Lu, H. Khan, M.Ishtiaq, S. Khan, M. Waqas, L. Wei and T. Wang .2013. Heavy metals in agricultural soils and crops and their health risks in Swat District, northern Pakistan. Food Chem Toxicol, 58: 449-458.

Khan, M.U., M. Said, R.N.Malik, S.I.Khan and M.Tariq .2015. Heavy metals potential health risk assessment through consumption of wastewater irrigated wild plants: A case study, Human and Ecological Risk Assessment: An International Journal, 22(1), 141-152

Khan, Z. I., Arshad, N., Ahmad, K., Nadeem, M., Ashfaq, A., Wajid, K., ... \& Ugulu, I. (2019). Toxicological potential of cobalt in forage for ruminants grown in polluted soil: a health risk assessment from trace metal pollution for livestock. Environmental Science and Pollution Research, 26(15), 15381-15389.

Krupa, W., L.Sołtys and M.Budzyńska .2006. Evaluation of themineral composition of hair in the Arabian mare considering thegenealogical lines. Ann Univ Mariae Curie SkłodowskaLublin, 24:209-21637.

Li, C., K.Zhou, W. Qin, C. Tian, M.Qi, X.Yan, W.Han.(2019. A review on heavy metals contamination in soil: effects, sources, and remediation techniques. Soil and Sediment Contamination: An International Journal, 28(4), $380-394$.

Li, G.C, L.H. Tarn, L.C.Sen .1994. Uptake of heavy metals by plants in Taiwan, paper from conference title: biogeochemistry of trace elements. Environ Geochem Health 2:153-160

Liang, Y.,L. Lei, J.Nilsson, H.Li, M. Nordberg, A. Bernard and T.Jin.2012. Renal function after reduction in cadmium exposure: an 8-year follow-up of residents in cadmium-polluted areas. Environmental health perspectives, 120(2): 223- 
228.

Liu, W.H., J.Z.Zhao , Z.Y.Ouyang , L.Soderlund, G.H.Liu .2005. Impacts of sewage irrigation on heavy metal distribution and contamination in Beijing, China. Environ Int, 31: 805-812.

Liu, Y., and X.Cao. 2016. Characteristics and significance of the pre-metastatic niche. Cancer cell, 30(5):668-681.

MAPANDA, F., E. MANGWAYANA, J.NYAMANGARA, K.GILLER .2005. The effect of long-term irrigation using wastewater on heavy metal contents of soils under vegetables in Harare, Zimbabwe. Agric Ecosyst Environ. 107, 151.

Murtaza, G., M.Zia-ur-Rehman, I.Rashid, M. Qadir .2019. Use of poor-quality water for agricultural production. In Research developments in saline agriculture (pp. 769-783). Springer, Singapore.

Nawab, J., S.Khan and M.T.Shah .2015. Contamination of soil, medicinal, and fodder plants with lead and cadmium present in mine-affected areas, Northern Pakistan. Environ Monit,187, 605.

Nwude, D.O., P.A.C.Okoye and J.O.Babayemi .2010. Heavy metal level in animal muscle tissue. A case study of Nigeria raised cattle. Res J App/ Sci 5(2): 146-150.

Okareh, O.T and T.A.Oladipo .2015. Determination of Heavy Metals in Selected Tissues and Organs of Slaughtered Cattle from Akinyele Central Abattoir, Ibadan, Nigeria. Journal of Biology, Agriculture and Healthcare, 5(11):2224-3208.

Pescod ,M.D.1992. Wastewater Treatment and Use in Agriculture. Irrigation and drainage paper. 47. Food and Agricultural Organization, Rome.

Rabee, A. M.,Y. F.Al-Fatlawy, A.A.H.N.Abd own and M. Nameer .2011. Using Pollution Load Index (PLI) and Geoaccumulation Index (I-Geo) for the Assessment of Heavy Metals Pollution in Tigris River Sediment in Baghdad Region. Al-Nahrain Journal of Science, 14(4), 108-114.

Ruchuwararak,P.,I. Somsak, B.Tengjaroenkul and L.Neeratanaphan .2019. Bioaccumulation of heavy metals in local edible plants near a municipal landfill and the related human health risk assessment, Human and Ecological Risk Assessment: An International Journal, 25(7):1760-1772.

Sharma, P and R.S.Dubey .2005. Lead toxicity in plants. Braz J Plant Physiol 17: 35-52.

Su, C., J.Zhang, Z. Li, Q. Zhao, K. Liu, Y. Sun, and J. Wang .2017. Accumulation and Depletion of Cadmium in the Blood, Milk, Hair, Feces, and Urine of Cows During and After Treatment. Biological trace element research, 175(1), 122-128.

SUZUKI, K., T.YABUKI and Y.ONO .2009. Roadside Rhododendron pulchrum leaves as bioindicators of heavy metal pollution in traffic areas of Okayama, Japan. Environ. Monit. Assess., 149: 133-141.

Ubwa, S. T., R.Ejiga, P.A.C.Okoye and Q.M.Amua .2017. Assessment of Heavy Metals in the Blood and Some Selected Entrails of Cows, Goat and Pigs Slaughtered at Wurukum Abattoir, Makurdi-Nigeria. Advan Anal Chem, 7(1): 7-12.

Yang, X., Q.Li, Z.Tang, W.Zhang, G.Yu, Q.Shen and F.J.Zhao.2017. Heavy metal concentrations and arsenic speciation in animal manure composts in China. Waste Management, 64, 333-339.

Yu, X., Z.Wang , A.Lynn, J.Cai , Y.Huangfu , Y.Geng , J.Tang and X.Zeng .2016. Heavy metals in wheat grown in sewage irrigation: a distribution and prediction model. Pol J Environ Stud 25:413-418

\section{Tables 2-8}

Page $10 / 15$ 
Table: 2 Analysis of variance of data for cadmium in soil, forages and animals treated with Ground, canal and municipal wastewater

\begin{tabular}{|c|c|c|}
\hline Source & Degree of freedom & Mean Square \\
\hline Site & 2 & $2.021 * * *$ \\
\hline Soil & 4 & $0.343^{\mathrm{ns}}$ \\
\hline \multirow[t]{2}{*}{ Site * Soil } & 8 & $0.197^{\mathrm{ns}}$ \\
\hline & Forages & \\
\hline Site & 3 & $1.572^{* * *}$ \\
\hline Forage & 4 & $0.435^{*}$ \\
\hline \multirow[t]{2}{*}{ Site $*$ Forage } & 12 & $0.586^{* * *}$ \\
\hline & \multicolumn{2}{|c|}{ Animals } \\
\hline Site & 2 & $7.471 * * *$ \\
\hline Animal & 2 & $1.576^{\mathrm{ns}}$ \\
\hline Source & 2 & $1.244^{\mathrm{ns}}$ \\
\hline Site * Animal & 4 & $0.583^{\mathrm{ns}}$ \\
\hline Site * Source & 4 & $0.818^{\mathrm{ns}}$ \\
\hline Animal * Source & 4 & $2.785^{* * *}$ \\
\hline Site * Animal * Source & 8 & $0.779^{\text {ns }}$ \\
\hline \multicolumn{3}{|c|}{ Water } \\
\hline Between Groups & 2 & $0.284^{* *}$ \\
\hline Within Groups & 6 & 0.015 \\
\hline
\end{tabular}

Table: 3 Concentration of Cadmium ( $\mathrm{mg} / \mathrm{kg}$ ) in collected soil and forage sample (Mean \pm S.E)

\begin{tabular}{|lccccccc|}
\hline Sites & & & FORAGE & & & SOIL \\
& & GWI-I & CWI-II & MWW-III & GWI-I & CWI-II & MWW-III \\
Soil of & B. vulgaris & $0.62 \pm 0.25$ & $0.73 \pm 0.08$ & $0.90 \pm 0.07$ & $0.817 \pm 0.05$ & $1.03 \pm 0.11$ & $0.850 \pm 0.16$ \\
Soil of & B. campestris & $0.503 \pm 0.06$ & $1.39 \pm 0.19$ & $1.45 \pm 0.16$ & $0.830 \pm 0.09$ & $1.79 \pm 0.23$ & $1.36 \pm 0.10$ \\
Soil of & T. alexandrinum & $0.393 \pm 0.05$ & $1.35 \pm 0.41$ & $1.68 \pm 0.65$ & $0.833 \pm 0.09$ & $1.43 \pm 0.23$ & $1.93 \pm 0.49$ \\
Soil of & S. officinarum & $0.68 \pm 0.12$ & $0.66 \pm 0.20$ & $0.35 \pm 0.068$ & $0.797 \pm 0.16$ & $1.59 \pm 0.32$ & $1.46 \pm 0.40$ \\
Soil of & C . album & $0.49 \pm 0.01$ & $1.15 \pm 0.14$ & $1.76 \pm 0.30$ & $0.830 \pm 0.08$ & $1.75 \pm 0.27$ & $1.27 \pm 0.26$ \\
\hline
\end{tabular}

Table: 4 Concentration of Cadmium $\mathrm{mg} / \mathrm{kg}$ in animals (Mean+ S.E) 


\begin{tabular}{|l|l|l|l|l|}
\hline Sources & Animals & \multicolumn{3}{l}{ Study sites } \\
\cline { 3 - 5 } & & GW I & CW II & MWW III \\
\hline Blood & Cow & $1.39 \pm 0.27$ & $1.98 \pm 0.35$ & $1.66 \pm 0.28$ \\
& Buffalo & $1.26 \pm 0.18$ & $1.45 \pm 0.21$ & $1.03 \pm 0.11$ \\
& Sheep & $0.864 \pm 0.05$ & $1.48 \pm 0.26$ & $1.05 \pm 0.19$ \\
Hair & Cow & $1.30 \pm 0.23$ & $1.96 \pm 0.39$ & $1.33 \pm 0.22$ \\
& Buffalo & $1.21 \pm 0.19$ & $2.03 \pm 0.35$ & $0.91 \pm 0.13$ \\
& Sheep & $2.025 \pm 0.18$ & $1.98 \pm 0.360$ & $1.10 \pm 0.12$ \\
Feces & Cow & $1.19 \pm 0.25$ & $1.06 \pm 0.27$ & $0.961 \pm 0.20$ \\
& Buffalo & $1.21 \pm 0.19$ & $1.19 \pm 0.26$ & $1.141 \pm 0.15$ \\
& Sheep & $1.75 \pm 0.20$ & $2.32 \pm 0.32$ & $1.14 \pm 0.25$ \\
\hline
\end{tabular}

Table: 5 Concentration of cadmium $\mathrm{mg} / \mathrm{kg}$ in collected water sample (Mean \pm S.E).

\begin{tabular}{|lccc|}
\hline Sources & Mean S.E & Minimum & Maximum \\
GW I & 0.5830 .08 & 0.42 & 0.71 \\
CW II & 1.160 .06 & 1.06 & 1.29 \\
MWW III & 1.0570 .05 & 0.94 & 1.12 \\
\hline
\end{tabular}

Table: 6 pollution load index, Bioconcentration factor and Enrichment factor for cadmium from soil to Forage

\begin{tabular}{|l|l|l|l|l|l|l|l|l|l|}
\hline \multirow{2}{*}{ Forages } & \multicolumn{2}{|l|}{ EF } & \multicolumn{4}{|c|}{ PLI } & \multicolumn{3}{c|}{ BCF } \\
\cline { 2 - 10 } & GW I & CW II & MWW III & GW I & CW II & MWW III & GW I & CW II & MWW III \\
\hline B. vulgaris & 5.654 & 5.280 & 7.862 & 0.292 & 0.368 & 0.304 & 0.756 & 0.709 & 1.055 \\
\hline B. campestris & 4.515 & 5.785 & 7.959 & 0.296 & 0.639 & 0.486 & 0.606 & 0.777 & 1.068 \\
\hline T.alexandrinum & 3.515 & 7.033 & 6.484 & 0.298 & 0.511 & 0.689 & 0.468 & 0.944 & 0.870 \\
\hline S. officinarum & 6.356 & 3.107 & 1.77 & 0.285 & 0.568 & 0.521 & 0.850 & 0.417 & 0.238 \\
\hline C. album & 4.398 & 4.895 & 10.32 & 0.294 & 0.625 & 0.454 & 0.598 & 0.657 & 1.386 \\
\hline
\end{tabular}

Table: 7 Daily intake of cadmium by animals via intake of contaminated forages. 


\begin{tabular}{|l|l|l|l|l|l|l|l|l|l|}
\hline \multicolumn{1}{|c|}{ Forages } & \multicolumn{3}{|c|}{ Cow } & \multicolumn{3}{c|}{ Buffalo } & \multicolumn{3}{c|}{ Sheep } \\
\hline B. vulgaris & 0.00105 & 0.00124 & 0.0015 & 0.00119 & 0.0014 & 0.00173 & 0.00913 & 0.0107 & 0.0132 \\
\hline B. campestris & 0.00085 & 0.0023 & 0.0024 & 0.00097 & 0.00268 & 0.0028 & 0.00741 & 0.0204 & 0.0213 \\
\hline T. alexandrinum & 0.00066 & 0.0022 & 0.0028 & 0.00075 & 0.0026 & 0.00324 & 0.0057 & 0.019 & 0.0247 \\
\hline S. officinarum & 0.00115 & 0.0011 & 0.00058 & 0.0013 & 0.00128 & 0.00067 & 0.01001 & 0.0097 & 0.0051 \\
\hline C. album & 0.00083 & 0.00195 & 0.0029 & 0.00094 & 0.00222 & 0.0034 & 0.0072 & 0.0169 & 0.025 \\
\hline
\end{tabular}

Table: 8

Table 8: Health risk index of cadmium for animals via intake of contaminated forages

\begin{tabular}{|l|l|l|l|l|l|l|l|l|l|}
\hline Cd & \multicolumn{3}{|c|}{ Cow } & \multicolumn{5}{c|}{ Buffalo } & \multicolumn{3}{c|}{ Sheep } \\
\hline B. vulgaris & 1.05 & 1.24 & 1.52 & 1.19 & 1.41 & 1.73 & 9.13 & 10.76 & 13.22 \\
\hline B. campestris & 0.855 & 2.36 & 2.47 & 0.972 & 2.69 & 2.80 & 7.41 & 20.48 & 21.36 \\
\hline T.alexandrinum & 0.668 & 2.29 & 2.86 & 0.759 & 2.61 & 3.25 & 5.79 & 19.89 & 24.75 \\
\hline S. officinarum & 1.16 & 1.13 & 0.589 & 1.31 & 1.28 & 0.669 & 10.01 & 9.77 & 5.11 \\
\hline C. album & 0.833 & 1.95 & 2.99 & 0.947 & 2.22 & 3.40 & 7.22 & 16.94 & 25.93 \\
\hline
\end{tabular}

\section{Figures}

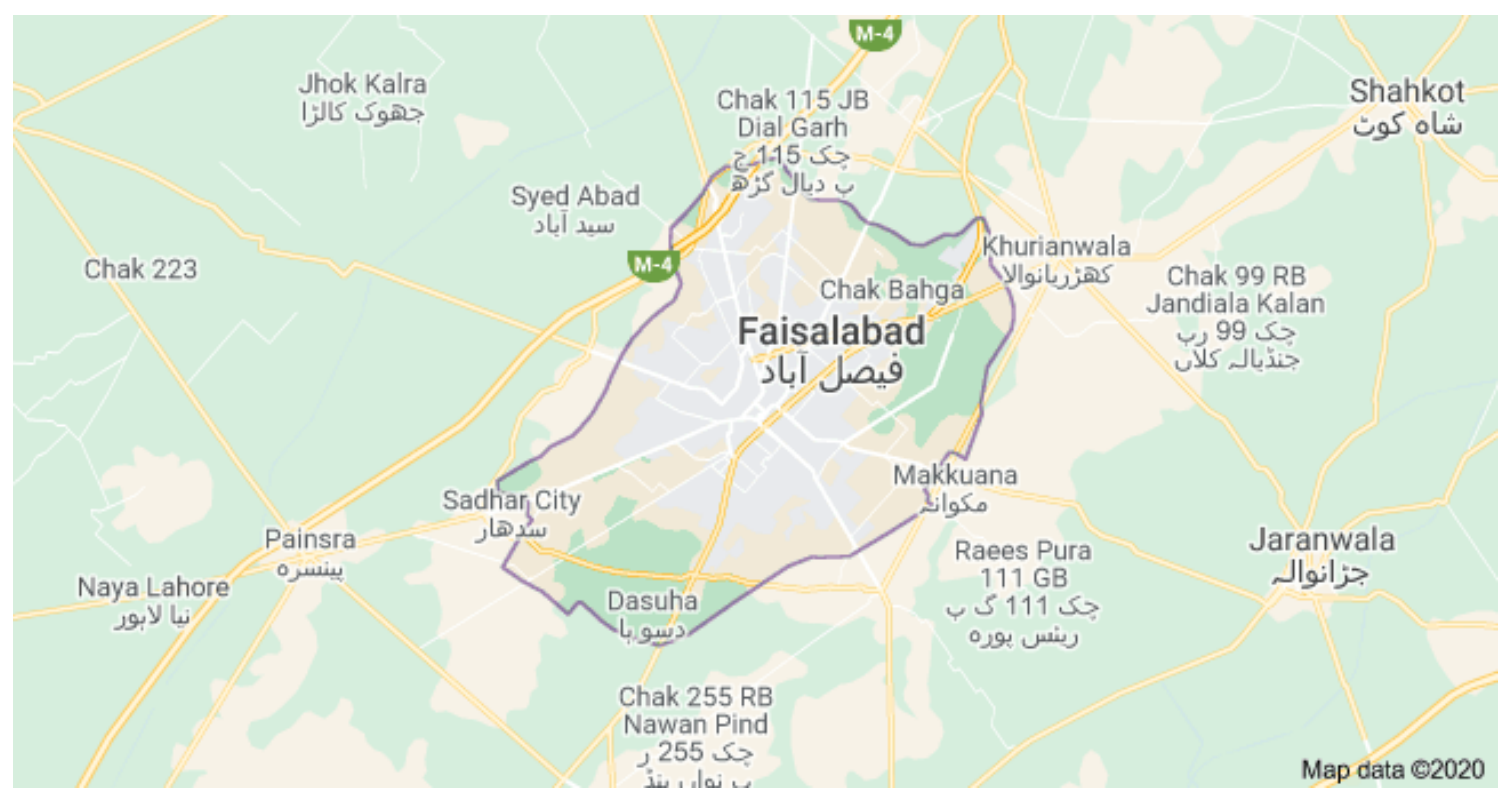

\section{Figure 1}

Map of study area. 


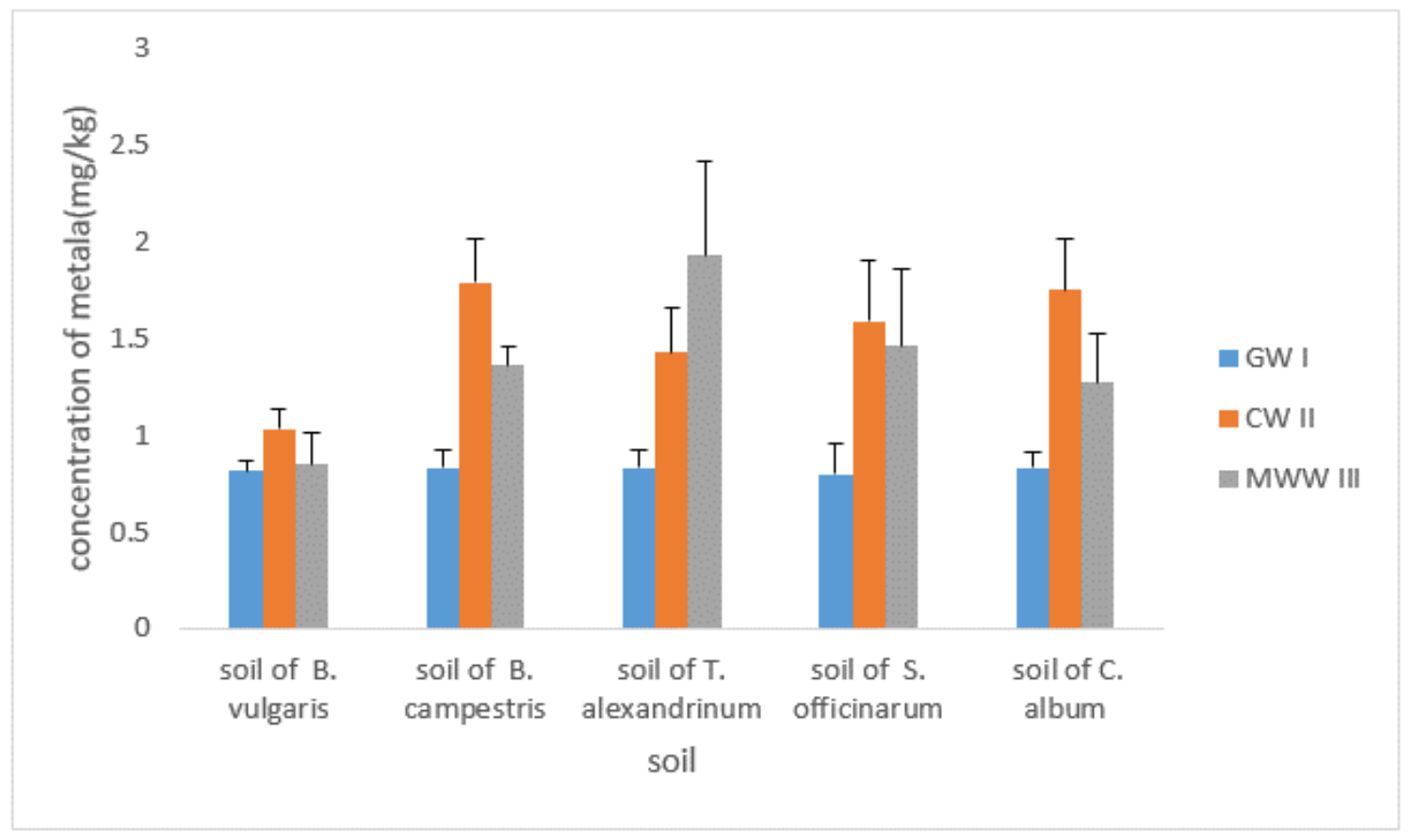

Figure 2

Fluctuation in level of cadmium in soil treated with Ground, canal and municipal wastewater

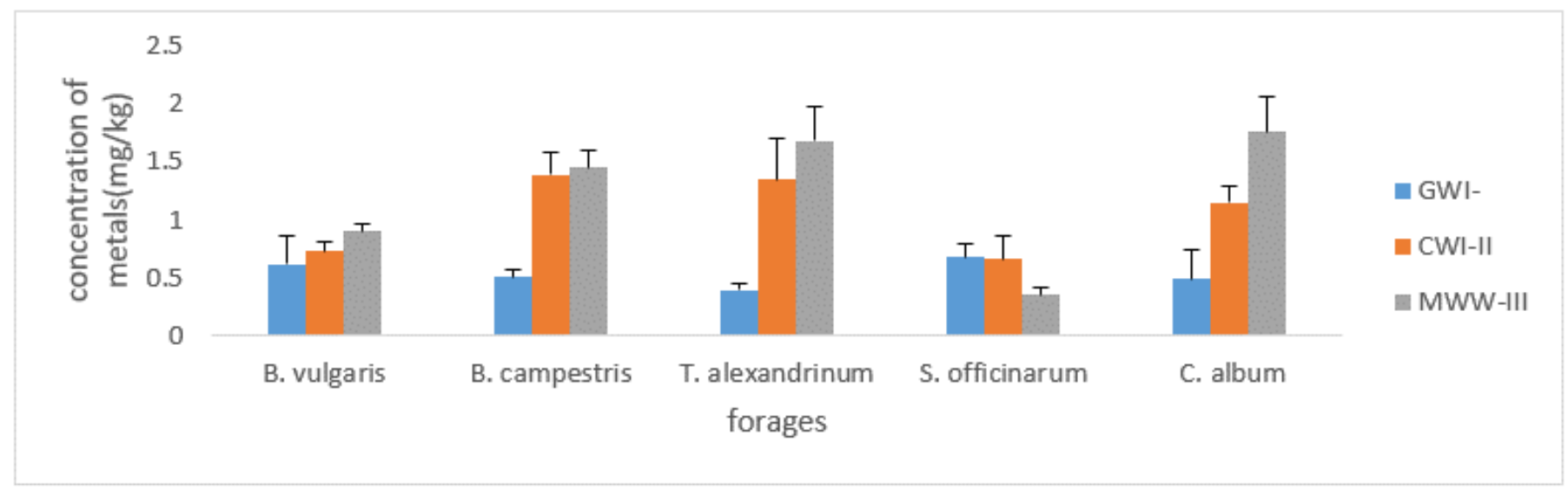

Figure 3

Fluctuation in level of cadmium in forages

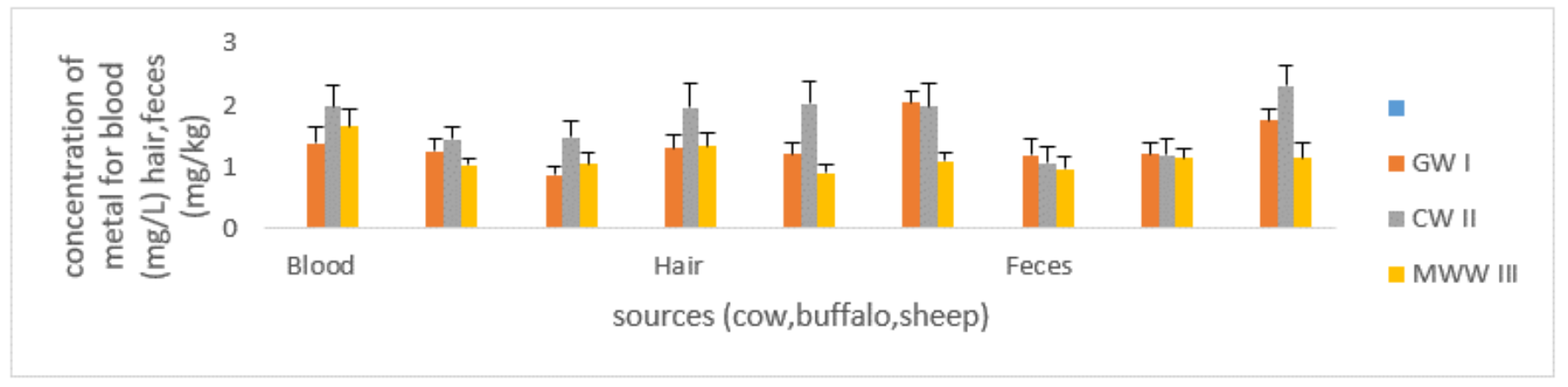

Figure 4 
Fluctuation in level of cadmium in animals

Page 15/15 